Note

\title{
Degradation of Soybean Protein by an Acid Proteinase from Monascus anka
}

\author{
Masaaki YASUDA and Maki SAKAGUCHI \\ Department of Bioscience and Biotechnology, College of Agriculture, University of the Ryukyus, l, Senbaru, Nishihara-cho, Okinawa \\ 903-0213, Japan
}

Received April 24, 1997; Accepted September 17, 1997

\begin{abstract}
Degradation of soybean protein by Monascus-proteinase was investigated in order to reveal the role of the enzyme in the process of tofuyo ripening. The ratio of trichloroacetic acid-insoluble nitrogen of soybean protein to the total nitrogen in the reaction mixture decreased with increasing enzymatic reaction time. It was found that the digestion of soybean protein by this enzyme progressed as follows: initially, $\alpha^{\prime}-, \alpha$-, and $\beta$-subunits in $\beta$-conglycinin, and then, the acidic subunit in glycinin were degraded. However, the basic subunit of glycinin still remained, and some polypeptide bands (around $10 \mathrm{kDa}$ ) were formed during the enzyme reaction. The degradation rate of soybean protein by this enzyme was affected by the ethyl alcohol concentration in the reaction mixtures.
\end{abstract}

Keywords: soybean protein, degradation, acid proteinase, Monascus fungus, red koji, tofuyo

The mold Monascus has been used for tofuyo and food coloring in Okinawa Prefecture, Japan (Yasuda, 1983). Tofuyo is a vegetable protein food made from tofu by the action of microorganisms. This food is a creamy cheese-type product with a mild flavor, fine texture, and good taste. It is unique and characteristic that the ripening was carried out in the presence of the ethyl alcohol of awamori (Okinawan traditional distilled liquor) (Yasuda, 1990). Changes in soybean protein and nitrogen compounds (Yasuda et al, 1993, 1994) and physical changes (Yasuda et al., 1996) of tofuyo during the ripening period were examined in order to reveal the ripening mechanism. An acid proteinase from Monascus anka (Monascus-proteinase) is considered to serve as a key enzyme for the ripening of the product. Although fungal proteinases have been extensively investigated (Fukumoto et al., 1967; Ichishima, 1970; Tsujita \& Endo, 1977), information on the enzyme produced by Monascus fungus was very limited. The authors reported the purification and some properties of acid proteinase obtained from red koji of Monascus fungus which was used for making tofuyo (Yasuda et al., 1984).

In this paper, the effects of ethyl alcohol on the activities of the purified Monascus-proteinase and the mode of action toward soybean protein are described.

\section{Materials and Methods}

Microorganism, cultivation and purification of the enzyme The microorganism used throughout this study was Monascus anka No. 3403 which was isolated in our laboratory from the red koji obtained in Hong Kong. The culture of the microorganism and purification of the enzyme used in this work were carried out as previously reported (Yasuda et al., 1984). The purified enzyme was confirmed to be homogeneous by disc-gel electrophoresis and sodium dodecyl sulfate (SDS)-polyacrylamide gel electrophoresis.

Assay method Proteinase activity was assayed as in our previous paper (Yasuda et al., 1984), except soybean protein isolate (SPI). The amounts of trichloroacetic acid (TCA)-soluble nitrogen which formed by the enzyme reaction were determined by the following methods: The reaction mixture, containing $5.0 \mathrm{ml}$ of $2 \% \mathrm{SPI}$ solution, $5.0 \mathrm{ml}$ of $0.4 \mathrm{M}$ lactate buffer ( $\mathrm{pH} 3.0$ ), $10 \mathrm{ml}$ of enzyme solution $(15.6 \mu \mathrm{g} / \mathrm{ml})$, and toluene, was incubated at $37^{\circ} \mathrm{C}$ for an appropriate reaction time with shaking. After the enzyme reaction, $1 \mathrm{ml}$ of $0.4 \mathrm{M}$ TCA solution was added to $1.5 \mathrm{ml}$ of the reaction mixture, and the reaction was stopped. Thereafter, the reaction mixture was filtrated with Toyo-filter paper No. 5B. The amounts of nitrogen in the filtrate (TCA-soluble nitrogen) or in the residue (TCA-insoluble nitrogen) were determined by a micro kjeldahl method ("Nippon Shokuhin Kogyo Gakkai," 1982; Yasuda et al., 1993).

Slab SDS-polyacrylamide gel electrophoresis The samples for gel electrophoresis were prepared as follows: The enzyme reaction was carried out as previously described. After the enzyme reaction, $187.5 \mu$ l of SDS-buffer ( $\beta$-mercaptoethanol: $0.5 \mathrm{M}$ Tris- $\mathrm{HCl}$ buffer $(\mathrm{pH} \mathrm{6.8):} 10 \%$ sodium dodecyl sulfate solution; 50:125:100, v/v/v) was added to 1 $\mathrm{ml}$ of the reaction mixture, followed by boiling for $2 \mathrm{~min}$. Each sample was then lyophilized.

Slab SDS-gel electrophoresis in $15 \%$ polyacrylamide gel $(10 \times 14 \times 0.2 \mathrm{~cm})$ was performed according to the method of Laemmli with a pH 8.3 buffer system (Laemmli, 1970). After the run, the protein was stained with $0.25 \%$ Coomassie brilliant blue in a methanol-acetic acid solution (methanol: acetic acid: water; 50: 10: 43, v/v/v) at room temperature.

\section{Results and Discussion}

Effect of ethyl alcohol on the enzyme activity The effect of ethyl alcohol on the activity of the enzyme used in this work is shown in Fig. 1. The enzyme activity decreased as the ethyl alcohol concentration increased. The relative activities of 10,20 , and $30 \%$ ethyl alcohol in the reaction 


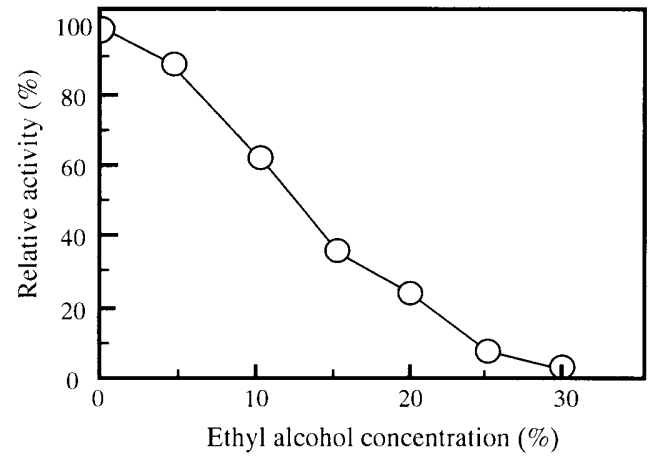

Fig. 1. Effect of ethyl alcohol on the activity of Monascus-proteinase.

mixture, were 63,25 , and $3 \%$, of the nonalcohol treatment, respectively. It is known that the maturation of tofuyo progresses in the presence of $15-20 \%$ ethyl alcohol. Thus, it is considered that the protein of tofu is degraded slowly, being affected by reduced proteinase activities (Yasuda et al., 1993).

Effect of ethyl alcohol on the degradation of soybean protein by the enzyme To learn the extent of the hydrolysis of soybean protein by the enzyme isolated in this work, ethyl alcohol was added to the reaction mixture. Changes in the ratio of the TCA-soluble nitrogen content to the total nitrogen in the reaction product are shown in Fig. 2. It was found that these values rapidly increased with initial reaction time (until $1 \mathrm{~h}$ ), after that, they increased slowly, and the ratio was affected by the concentration of the ethyl alcohol in the reaction mixture. Soybean protein was converted to low molecular weight compounds such as peptides and amino acids, being affected by these proteinase activities. It is thought that the enzyme contributes to the formation of tasty amino acids such as glutamic acid and aspartic acid together with carboxypeptidase, amino peptidase and glutaminase etc., and these amino acids are closely related to the tastes of tofuyo (Yasuda et al., 1993, 1994).

Mode of action toward soybean protein by the enzyme Digestion of soybean protein by the enzyme was examined by the method of slab SDS-polyacrylamide gel electrophoresis (SDS-PAGE) in the presence of $\beta$-mercaptoethanol. The SDS-PAGE pattern of the soybean protein at various enzyme reaction stages in the presence of $20 \%$ ethyl alcohol is shown in Fig. 3. Each polypeptide band corresponding with $\alpha^{\prime}-, \alpha$-, and $\beta$-subunits in $\beta$-conglycinin, and the acidic and basic subunits in glycinin were observed after 0 min incubation. After 30-min incubation, some polypeptide bands (10-12 $\mathrm{kDa}$ ) increased. The bands of $\alpha^{\prime}-, \alpha$, and $\beta$-subunits in $\beta$-conglycinin disappeared after a 4 -h incubation, but the acidic subunit in glycinin was thin, and that of the basic subunit and other relatively low molecular weight polypeptide bands (around $10 \mathrm{kDa}$ ) were detected after 24-h incubation.

When ethyl alcohol was absent, the SDS-PAGE pattern of soybean protein at various enzyme reaction stages was examined (the data are not shown). Some polypeptide bands appeared in molecular mass $\left(10^{-15} \mathrm{kDa}\right)$ after 5-min incubation, and the bands of $\alpha^{\prime}-\alpha$-, and $\beta$-subunits in $\beta$-congly-

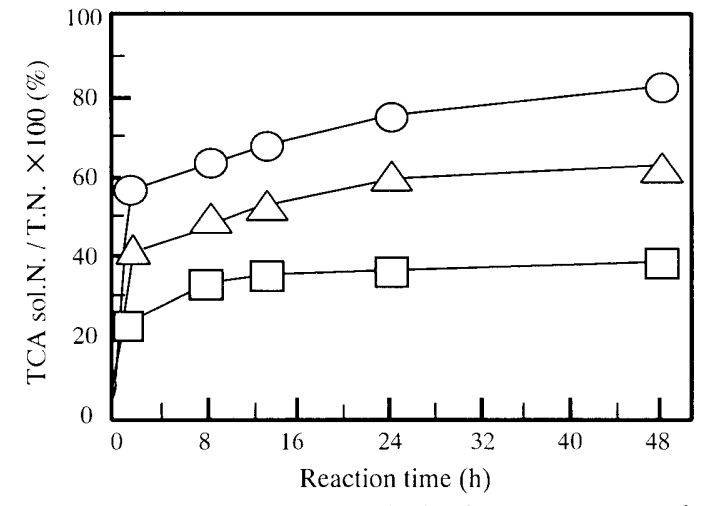

Fig. 2. Changes in the ratio of TCA-soluble nitrogen content to the total nitrogen of soybean protein during the enzyme reaction. $0 \%$ ethyl alcohol, $\triangle$ $10 \%$ ethyl alcohol, L. 20\% ethyl alcohol.

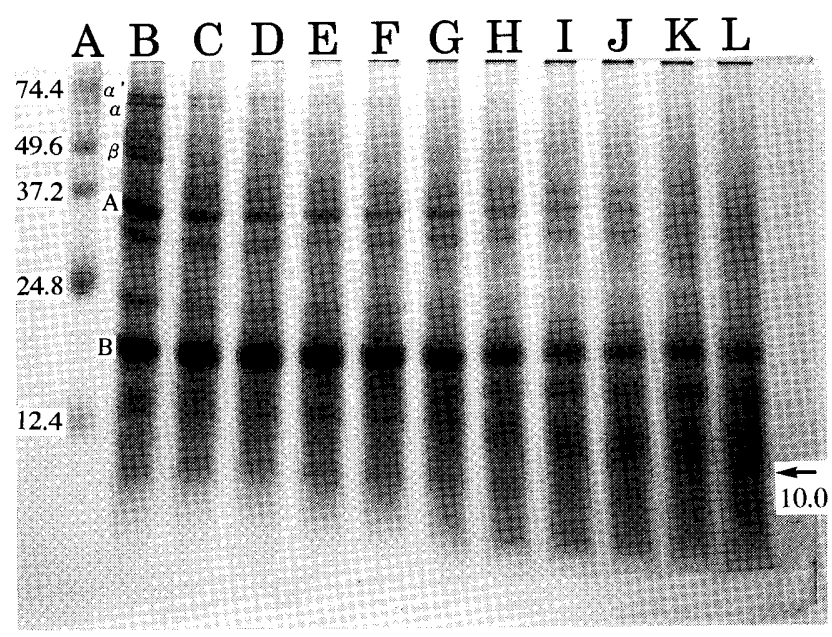

Fig. 3. Slab SDS-polyacrylamide gel electrophoretic pattern of soybean protein at various enzyme reaction stages. Preparation of the samples was described in the text. The enzyme reaction was carried out in the presence of $20 \%$ ethyl alcohol. Molecular weights were estimated by the mobilities of cytochrome $\mathrm{c}$ from horse heart and crossed-linked cytochrome $\mathrm{c}$ (cytochrome c monomer, dimer, trimer, tetramer and hexamer). A: Standard proteins described above, B: $0 \mathrm{~min}, \mathrm{C}: 5 \mathrm{~min}, \mathrm{D}: 10 \mathrm{~min}, \mathrm{E}: 15 \mathrm{~min}, \mathrm{~F}: 20 \mathrm{~min}, \mathrm{G}: 30$ min, H: 1 h, I: 2 h, J: 4 h, K: 8 h, L: 24 h. Numerical values in lanes A and L showed each molecular mass (kDa). Symbols of $\alpha^{\prime}, \alpha$ and $\beta$ in lane B showed $\alpha^{\prime}-, \alpha$ - and $\beta$-subunits in $\beta$-conglycinin, and A and B in lane B showed Acidic and basic subunits in glycinin.

cinin, and the acidic subunit in glycinin disappeared after 10 -min incubation, but that of the basic subunit in glycinin still remained after 24 -h incubation. When $10 \%$ ethyl alcohol was present, the band of the acidic subunit disappeared after 2-h incubation.

From these results, it was found that the degradation of soybean protein by this enzyme progressed as follows: initially, each subunit in $\beta$-conglycinin, and then, the acidic subunit in glycinin were degraded. However, its basic subunit still remained, and some polypeptide bands (around $10 \mathrm{kDa}$ ) were formed during the enzyme reaction. It is thought that the difficulty of the degradation of the basic subunit originates in the substrate specificity of the enzyme. The degradation rate of soybean protein by this enzyme was affected by the ethyl alcohol concentration in the reaction mixture. These phenom- 
ena were in good agreement with the case of tofuyo during the ripening period (Yasuda et al., 1993). Namely, Monascusproteinase gradually degraded the protein of tofu (especially, each subunit in $\beta$-conglycinin and the acidic subunit in glycinin) in the presence of the ethyl alcohol of awamori in moromi and formed polypeptides (around $10 \mathrm{kDa}$ ), peptides, and amino acids during fermentation. However, it could not degrade the basic subunit in glycinin (Yasuda et al., 1993, 1994, 1995). These formed polypeptides and the remaining glycinin which has strong gel-forming ability are closely related with the body of tofuyo (Yasuda et al., 1993, 1995), and it is considered that the glycinin greatly contributes to preserving the good textures of tofuyo (Yasuda et al., 1996). Thus, we concluded that Monascus-proteinase is a key enzyme for tofuyo ripening.

Acknowledgments This work was supported in part by a Grant-in Aid for Scientific Research (No. 04660148) from the Ministry of Education, Science, Sports, and Culture of Japan.

\section{References}

Fukumoto, J., Tsuru, D. and Yamamoto, T. (1967). Purification, crystallization and some enzymatic properties of acid protease of Rhizopus chinensis. Agric. Biol. Chem., 31, 710-717.

Ichishima, E. (1970). Purification and mode of assay for acid proteinase of Aspergillus saitoi. In "Methods in Enzymology," Vol. XIX, ed. by E. Perman and L. Lorand. Academic Press, Inc. New York, pp. 397-406.
Laemmli, U.K. (1970). Cleavage of structural properties during the assembly of the head of bacteriophage T4., Nature, 227, 680-685.

Nippon Shokuhin Kogyo Gakkai. Shokuhin Bunseki Henshu Iinkai (1982). "Shokuhin Bunsekiho," Kohrin, p. 102 (in Japanese).

Tsujita, Y. and Endo, A. (1977). Extra cellular acid protease of Aspergillus oryzae grown on liquid media: Multiple forms due to association with heterogeneous polysaccharides. J. Bacteriol., 130, $48-56$.

Yasuda, M. (1983). Tofuyo and red koji. Nippon Jozokyokai Zasshi, 77, 839-842, 912-915 (in Japanese).

Yasuda, M., Soeishi, K. and Miyahira, M. (1984). Purification and properties of acid protease from Monascus sp. No. 3403. Agric. Biol. Chem., 48, 1637-1639.

Yasuda, M. (1990). A scientific analysis for producing procedures of tofuyo, and its technical developments. Nippon Shokuhin Kogyo Gakkaishi, 37, 403-409 (in Japanese).

Yasuda, M., Matsumoto, T., Sakaguchi, M. and Kobamoto, N. (1993). Changes in chemical components of tofuyo prepared by Monascus fungus during ripening fermentation. Nippon Shokuhin Kogyo Gakkaishi, 40, 331-338 (in Japanese).

Yasuda, M., Matsumoto, T., Sakaguchi, M. and Kinjyo, S. (1994). Changes in protein and nitrogen compounds of tofuyo prepared by Aspergillus oryzae during fermentation. Nippon Shokuhin Kogyo Gakkaishi, 41, 184-190 (in Japanese)

Yasuda, M., Matsumoto, T., Sakaguchi, M. and Kinjyo, S. (1995). Production of tofuyo using the combination of red and yellow kojis. Nippon Shokuhin Kagaku Kogakukaishi, 42, 38-43 (in Japanese).

Yasuda, M., Kinjyo, S. and Miki, E. (1996). Changes in breaking characteristics, creep behavior and micro structure of tofuyo during fermentation. Nippon Shokuhin Kagaku Kogakukaishi, 43, 322327 (in Japanese). 